
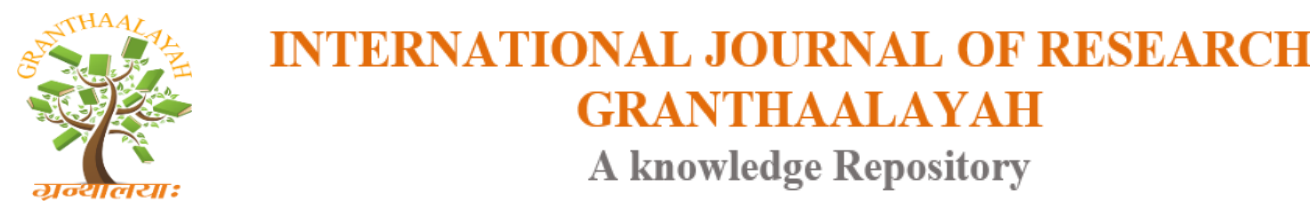

Science

\title{
QUALITY ATTRIBUTES OF COOKIES PRODUCED FROM COMPOSITE FLOURS OF WHEAT, GERMINATED FINGER MILLET FLOUR AND AFRICAN YAM BEAN
}

\author{
Abioye V.F ${ }^{* 1}$, Olatunde S.J ${ }^{2}$, Elias $\mathbf{G}^{3}$ \\ ${ }^{* 1,2,3}$ Department of Food Science and Engineering, Ladoke Akintola University of Technology, \\ Ogbomoso, Nigeria
}

\begin{abstract}
Cookies are ready to eat convenient food for all ages and the consumption is on the increase in Nigeria due to urbanization which has led to increase in wheat importation. In order to reduce the effects of wheat importation on the economy, this study looked into the use of locally grown crops for production of cookies. Cookie samples were produced from blends of wheat flour, germinated finger millet and African yam bean. Different proportions of flour blends were obtained using design experts. The flour mixes were evaluated for the proximate, minerals composition, antinutrients and the functional properties while the sensory properties of the cookies were determined. The proximate composition of the composite flour varied from 12.20-12.54; 8.89$10.62 ; 1.31-1.65 ; 1.13-1.39 ; 1.82-1.48$ and $74.33-72.66 \%$ for moisture, protein, fat, crude fibre, ash and carbohydrate content of the flour, respectively. The mineral content of the flour ranged from 9.064-9.10, $0.29-0.32,0.42-0.45,0.24-0.28 \%$ for calcium, phosphorus, potassium and sodium, respectively. The anti-nutritional properties of the flour ranged from 0.0074 to $0.0098 \%$, 0.1700 to $0.1990 \%, 0.0905$ to $0.1080 \%$ and 1.2500 to $1.4900 \%$, for tannin, phytate, oxalate and trysin inhibitor, respectively. The functional properties of the composite flour ranged from $0.66-$ $0.67 \mathrm{~g} / \mathrm{ml} ; 25.87-27.48 \mathrm{~g} / \mathrm{ml} ; 6.11-8.12 \mathrm{~g} / \mathrm{ml} ; 0.75-0.83 \mathrm{~g} / \mathrm{ml} ; 106.65$ to $124 ; 91.70-99.75 \mathrm{~g} / 100 \mathrm{~g}$; for bulk density, water absorption capacity, oil water capacity, foaming capacity and foaming solubility, respectively. The sensory attributes studied were colour, taste, texture and crispness. This study has shown that there was a notable improvement on the nutritional and functional properties of the flour while there was reduction in the ant nutrients.
\end{abstract}

Keywords: African Yam Bean; Finger Millet; Cookies; Wheat Flour; Snack; Composite Flour.

Cite This Article: Abioye V.F, Olatunde S.J, and Elias G. (2018). "QUALITY ATTRIBUTES OF COOKIES PRODUCED FROM COMPOSITE FLOURS OF WHEAT, GERMINATED FINGER MILLET FLOUR AND AFRICAN YAM BEAN." International Journal of Research Granthaalayah, 6(11), 172-183. https://doi.org/10.5281/zenodo.1845427. 


\section{Introduction}

Cookie is a conventional wheat flour-based food product produced from unpalatable dough with the application of heat and transformed into an appetizing product (Kulkarni, 1997; Obasi et al., 2012; Ikuomola et al., 2017). It forms part of the bakery products that are consumed extensively all over the world by all ages (Sengev et al., 2015). Cookies are ready to eat, convenient and inexpensive snack food products containing digestive and dietary principles of vital importance (Adeyeye and Akingbala, 2015). The principal ingredients are wheat flour, fat, sugar and water and optional ingredients include milk, salt, flavouring agent, aerating agent, food additives and others. Soft wheat flour has been the major ingredient used in the production of cookies but imported by countries with unfavorable climatic conditions such as Nigeria. The increase in the importation could lead to economic drain, high prices of these bakery products and a threat to food security. This necessitates a need for strategic development in the use of inexpensive local resources in the production of cookies.

Finger millet (Eleusine coracana $L$ ) is a small cereal grain grown in the semi-arid subtropical and tropical regions of Africa and Asia where it is one of the staples (Obilana and Manyasa, 2002). It is one of the most nutritious and healthy cereals with high protein and mineral contents (Chandrasekara et al., 2016; Wafula et al., 2018). Finger millet is rich in protein, mineral content, and dietary fiber, it is valuable because it contains the amino acid, methionine which is lacking in diet of hundreds of millions of the poor who lives on starchy stapes such as cassava, plantain, polished rice and maize meal but underutilized (Amadon et al., 2013). It is also rich in magnesium, phosphorous, potassium, iron and has been reported to have 5-30 times the calcium content found in other cereals (Devi et al., 2014; Kumar et al., 2016; Vinoth and Ravindhran, 2017).

African Yam Bean (Sphenostylis stenocarpa) (AYB) is an under-utilized food legume usually cultivated for its edible seeds and tubers in most Sub-Saharan African Countries (Azeke et al., 2005; Moyib et al., 2008). It is a good source of protein, carbohydrate, minerals and vitamins. AYB is rich in dietary fibre and other phytochemicals that may have positive effects on health (Ndidi et al., 2014; Ojinnaka et al., 2017; Onuoha et al., 2017). The primary challenge to wide consumption of African yam bean (AYB) includes hardness of the seed which results into longtime cooking and the antinutrient contents of the seed (Aremu and Ibirinde, 2012; Abioye et al., 2015). It is thus very important to find alternative utilization methods apart from cooking to prevent further neglect and promote cultivation.

Increase in urbanization coupled with growing number of working mothers, have profoundly contributed to the popularity and increased consumption of snack foods in Nigeria. The escalating cost of wheat importation and difficulty in cultivating wheat in the tropics has focused attention on the need to explore the use of alternative local flours as supplements or substitutes for wheat flour in the baking industry. There is also an increasing interest in the consumption of functional foods where the consumers are not only interested in the nutritional benefits of foods but also in the health benefits (Azzura and Paola, 2009). Finger millet is an important cereal because of the nutritive value and excellent storage properties but underutilized due to anti nutritional contents. These anti nutrients have been reported to be reduced to minimal value by processing such as soaking, germination, malting and fermentation (Soetan and Oyewole, 2009; Sokrab et al., 2012). African Yam Bean is also an underutilized grain legume in Nigeria though contain quality protein content. 
Several studies have reported the production of cookies with high nutritional and sensory properties from non-wheat-based composite flour (Akubor and Ukwuru, 2005; Singh et al., 2003; Chinma and Gernah, 2007; Agriga and Iwe, 2009; Ubbor and Akobundu, 2009; Ajanaku et al., 2011; Okpala and Okoli, 2011; Olapade and Adeyemo, 2014; Atobatele and Afolabi, 2016; Ikuomola et al., 2017; Taiwo et al., 2017). Finding further uses for finger millet ans AYB, hitherto underutilized in Nigeria, adds value to it by enhancing its cultivation, and by extension, the economy of the cultivators and intermediate processors. Therefore, this study was undertaken to produce cookies of acceptable quality from blends of wheat flour, germinated finger millet and roasted African yam bean.

\section{Materials and Methods}

\subsection{Material}

Finger Millet (Eleusine coracana) grains were obtained from Ahmadu Bello University, Zaria, Kaduna State, Nigeria. African Yam bean (Sphenostylis stenocarpa) seeds, were obtained from Genetic Resources Centre, Institute of Agriculture and Research Training, Ibadan, Nigeria (IAR\&T) while other ingredients; shortening, sugar, salt, eggs, milk powder, baking powder (Sodium bicarbonate) were obtained from a local market in Ogbomoso, Oyo State, Nigeria. All chemicals used for this research were of analytical grade.

\subsection{Methods}

\section{Production of Germinated Finger Millet}

One hundred grams (100 g) of finger millet grain was weighed, sorted to remove extraneous materials and surface sterilized for $30 \mathrm{~min}$ in a $1 \%$ sodium hypochlorite solution. These seeds were rinsed (five times) with distilled water $(1: 3 \mathrm{w} / \mathrm{v})$ and soaked in a glass beaker for $9 \mathrm{~h}$ in tap water $(1: 3 \mathrm{w} / \mathrm{v})$. The presoaked seeds were allowed to sprout on sterile germinating trays lined with filter paper and kept moist by layers of damp cotton wool. The seeds were germinated at room temperature $\left(28 \pm 1^{\circ} \mathrm{C}\right)$, samples were collected after $72 \mathrm{~h}$ and dried using cabinet dryer $\left(45^{\circ} \mathrm{C}\right.$ for $12 \mathrm{~h}$ ). The germinated seeds were ground, sieved and packaged in polyethylene bags until further analysis.

\section{Production of African Yam Bean Flour}

The African yam bean flour was prepared using the modified method described by Okoye et al. (2010). The African yam bean seeds was cleaned and sorted to remove pods and foreign materials such as stones, sticks and broken pods. The cleaned beans were roasted, manually dehulled, milled and sieved. The dried seeds was milled using attrition mill (Globe p44, China) and sieved using a $100 \mu \mathrm{m}$ mesh sieve. The flour was stored in a plastic container with lid in a refrigerator at $4{ }^{\circ} \mathrm{C}$ prior to production of cookies.

\section{Formulation of Composite Flour}

Blending of the flour samples to obtain composite flours was carried out using D-optimal mixture design (Design Expert 9.0). The design was based on wheat flour (50-100\%), geminated finger millet flour (0-30 \%) and roasted African yam bean (0-20\%) flour. The generated mixes are as shown in Table 1. 
Table 1: Trial runs of the blends as generated by D-optimal mixture design

\begin{tabular}{cccc}
\hline Trials & $\begin{array}{c}\text { Wheat Flour } \\
(\mathbf{W F})\end{array}$ & $\begin{array}{c}\text { Germinated Finger Millet } \\
(\text { GFM) }\end{array}$ & $\begin{array}{c}\text { African Yam beam } \\
\text { (AYB) }\end{array}$ \\
\hline A & 100 & 0 & 0 \\
B & 90 & 10 & 0 \\
C & 80 & 20 & 0 \\
D & 70 & 30 & 0 \\
E & 70 & 20 & 10 \\
F & 60 & 30 & 10 \\
G & 70 & 10 & 20 \\
H & 50 & 30 & 20 \\
\hline
\end{tabular}

Sample A $=100 \% \mathrm{WF}$

Sample B $=90 \% \mathrm{WF}, 10 \%$ GFM, 0\% AYB

Sample C $=80 \%$ WF, 20\% GFM, 0\% AYB

Sample D=70\% WF, 30\% GFM, 0\% AYB

Sample E $=70 \%$ WF, 20\% GFM, 10\% AYB

Sample F $=60 \%$ WF, 30\% GFM, 10\% AYB

Sample $\mathrm{G}=70 \% \mathrm{WF}, 10 \%$ GFM, 20\% AYB

Sample H=50\% WF, 30\% GFM, $20 \%$ AYB

\section{Preparation of Cookies}

The cookies were baked using the method of Ceserani et al. (2008). About $50 \mathrm{~g}$ of Fat and $40 \mathrm{~g}$ of sugar were creamed to a smooth consistency; eggs and milk were also added and mixed. The dry ingredients; flour (100 g), baking powder $(1 \mathrm{~g})$ and salt $(0.5 \mathrm{~g})$ were mixed together and added to the cream followed by the flavour (vanilla flavor) and nutmeg to form a dough. The dough was kneaded into uniform thickness, cut into shapes, placed in greased pans, egg washed .and baked at $150{ }^{\circ} \mathrm{C}$ for $20 \mathrm{~min}$. The cookies were packaged in cellophane bags prior to analysis.

\subsection{Analyses}

\section{Proximate Analysis}

The flour samples were analyzed for moisture, ash, crude fibre, protein $\left(\mathrm{N}^{*} 6.25\right)$, crude fat and the carbohydrate determined by difference according to the method described by AOAC (2005).

\section{Mineral Analyses}

Selected minerals, including calcium, phosphorus, potassium, and sodium were extracted from dry ashed samples and determined by atomic absorption spectrophotometer (AOAC, 2005).

\section{Antinutritional Factors}

The tannin content of the flour mixes was determined as described by Makkar et al. (1993) using Folin Denis Reagents. Phytate content was determined using spectrophotometric method as described by Pearson (1976). Trypsin inhibitor was determined according to the methods described by Arntfield et al. (1985) while the oxalate content of the samples was determined using titration method. 


\section{Functional Properties}

The bulk density of the flour samples was determined as described by Okaka et al. (1991). Water and oil absorption capacity of the flour was determined as described by Oyeyinka et al., (2013). The foam capacity (FC) and foam stability (FS) of the flour samples were determined as described by Narayana and Narsinga Rao (1982).

\section{Sensory Evaluation of Cookies Samples}

Sensory evaluation was carried out with 40 panelists in the sensory laboratory. Each panelist was served with cookies made from the flour mixes. Water was provided for rinsing between the samples. Panelists was required to evaluate the colour, flavor, taste, textue, crispiness, appearance and overall acceptance of the cookies using the 9-point hedonic scale with 1 dislike extremely and 9 like extremely.

\section{Statistical Analysis}

The results of the experiment was subjected to analysis of variance (ANOVA) and the mean was separated with the use of Duncan's multiple range test to detect significant difference $(p<0.05)$ among the sample.

\section{Results and Discussion}

\section{Results of the Proximate Contents of the Flour}

The proximate composition of the composite flour is as shown in Table 2. The moisture content of the flour ranged from 9.38 to $10.48 \%$. Moisture content is an indicator of shelf life stability; increase in moisture content enhances microbial contamination and chemical reactions that could lead to reduction in the food quality and stability. The moisture content is below $14 \%$ recommended for long period of storage, hence a good potential during storage (Adeleke and Odedeji, 2010, Ogunlakin et al., 2012). The protein content ranged from 8.89 to $12.62 \%$ with the control sample (100\%) having the lowest value $(8.89 \%)$ while the sample with $50 \%$ wheat flour, $30 \%$ germinated finger millet and $20 \%$ African yam bean had the highest. There was a gradual increase in the level of protein as germinated finger millet and African yam been were substituted into the wheat flour. This probably was as a result of the germination which increased the protein availability which could be due to biosynthesis during germination and due to high protein content of African yam bean (Ghavidal and Prakash, 2007).

The fat content of the flour ranged from 1.31-1.65\% with the sample with $100 \%$ wheat flour having the lowest value $(1.31 \%$ ) and the sample with $50 \%$ wheat flour, $30 \%$ germinated and $20 \%$ having the highest $(1.65 \%)$. There was little increase in the fat value as finger millet and African yam bean flour is been added, this might be attributed to the high fat content in African yam bean flour. Fat improves flavour and increase the mouth feel of foods and It is a significant factor in food formulation especially in the cookies (Eke and Akobundu, 1993; Iwe and Egwuekwe, 2010). The crude fibre content ranged between 1.13-3.39\% and higher values were recorded with addition of germinated finger millet flour and African yam bean flour. This may be attributed to the fact that Finger millet is a good source of fibre and also due to germination process which increased the fibre content of the flour. 
The ash and carbohydrate content of the flour ranged from 1.82-5.48 \% and 66.66-77.31\%, respectively. The ash content increased with increase in germinated finger flour and African yam bean flour substitution. There was decrease in the carbohydrate value as finger millet and African yam bean flour were substituted.

Table 2: Proximate Composition of Composite Flour

\begin{tabular}{|l|l|l|l|l|l|l|}
\hline Sample & $\begin{array}{c}\text { Moisture } \\
(\boldsymbol{\%})\end{array}$ & $\begin{array}{c}\text { Crude Protein } \\
(\boldsymbol{\%})\end{array}$ & $\begin{array}{c}\text { C/Fat } \\
(\mathbf{\%})\end{array}$ & $\begin{array}{c}\text { Crude Fibre } \\
(\boldsymbol{\%})\end{array}$ & $\begin{array}{c}\text { Ash } \\
(\boldsymbol{\%})\end{array}$ & $\begin{array}{c}\text { CHO } \\
(\boldsymbol{\%})\end{array}$ \\
\hline A & $9.54^{\mathrm{f}}$ & $8.89^{\mathrm{a}}$ & $1.31^{\mathrm{a}}$ & $1.13^{\mathrm{a}}$ & $1.82^{\mathrm{g}}$ & $77.31^{\mathrm{f}}$ \\
\hline B & $9.53^{\mathrm{f}}$ & $8.97^{\mathrm{b}}$ & $1.35^{\mathrm{b}}$ & $1.16^{\mathrm{b}}$ & $1.96^{\mathrm{f}}$ & $77.03^{\text {ef }}$ \\
\hline C & $9.49^{\mathrm{e}}$ & $9.06^{\mathrm{c}}$ & $1.36^{\mathrm{b}}$ & $1.23^{\mathrm{c}}$ & $2.71^{\mathrm{e}}$ & $76.15^{\mathrm{de}}$ \\
\hline D & $10.45^{\mathrm{d}}$ & $9.18^{\mathrm{c}}$ & $1.38^{\mathrm{c}}$ & $1.25^{\mathrm{c}}$ & $4.68^{\mathrm{e}}$ & $73.06^{\mathrm{d}}$ \\
\hline E & $9.44^{\mathrm{d}}$ & $10.29^{\mathrm{d}}$ & $1.39^{\mathrm{c}}$ & $2.27^{\mathrm{d}}$ & $3.63^{\mathrm{d}}$ & $72.98^{\mathrm{d}}$ \\
\hline F & $10.41^{\mathrm{c}}$ & $9.39^{\mathrm{e}}$ & $1.43^{\mathrm{d}}$ & $2.31^{\mathrm{d}}$ & $4.58^{\mathrm{c}}$ & $71.88^{\mathrm{c}}$ \\
\hline G & $9.38^{\mathrm{b}}$ & $10.58^{\mathrm{f}}$ & $1.45^{\mathrm{d}}$ & $3.35^{\mathrm{e}}$ & $2.53^{\mathrm{b}}$ & $72.71^{\mathrm{b}}$ \\
\hline H & $10.20^{\mathrm{a}}$ & $12.62^{\mathrm{g}}$ & $1.65^{\mathrm{e}}$ & $3.39^{\mathrm{e}}$ & $5.48^{\mathrm{a}}$ & $66.66^{\mathrm{a}}$ \\
\hline
\end{tabular}

Mean with the same superscript along the same column are not significantly different $(p>0.05)$.

Sample A $=100 \% \mathrm{WF}$

Sample B $=90 \% \mathrm{WF}, 10 \%$ GFM, 0\% AYB

Sample C $=80 \% \mathrm{WF}, 20 \%$ GFM, 0\% AYB

Sample D=70\% WF, 30\% GFM, 0\% AYB

Sample E $=70 \%$ WF, 20\% GFM, 10\% AYB

Sample F $=60 \% \mathrm{WF}, 30 \%$ GFM, $10 \%$ AYB

Sample G=70\% WF, $10 \%$ GFM, 20\% AYB

Sample H=50\% WF, 30\% GFM, $20 \%$ AYB

\section{Mineral Composition of Flour}

The mineral composition of the composite flour is shown in Table 3. The mineral content of the flour ranged from 9.06 to $12.10 \%, 0.29$ to $0.52,0.42$ to $0.55,0.24$ to 0.38 , for calcium, phosphorus, potassium and sodium, respectively. Higher values were recorded with germinated finger millet and African yam bean substitution. This could be attributed to high contents of these minerals in germinated finger millet and African yam bean. Finger millet has been reported to be a good source of minerals (Mibithi et al., 2000; Dykes and Rooney, 2006).

Table 3: Mineral composition of the composite flour

\begin{tabular}{|l|l|l|l|l|}
\hline Sample & Calcium (\%) & Phosphorus (\%) & Potassium (\%) & Sodium (\%) \\
\hline A & $9.06^{\mathrm{a}}$ & $0.29^{\mathrm{a}}$ & $0.42^{\mathrm{a}}$ & $0.24^{\mathrm{a}}$ \\
\hline B & $9.08^{\mathrm{a}}$ & $0.29^{\mathrm{a}}$ & $0.43^{\mathrm{a}}$ & $0.26^{\mathrm{b}}$ \\
\hline C & $10.08^{\mathrm{b}}$ & $0.30^{\mathrm{bc}}$ & $0.43^{\mathrm{bc}}$ & $0.26^{\mathrm{b}}$ \\
\hline D & $11.09^{\mathrm{bc}}$ & $0.50^{\mathrm{b}}$ & $0.53^{\mathrm{d}}$ & $0.36^{\mathrm{bc}}$ \\
\hline E & $9.09^{\mathrm{d}}$ & $0.30^{\mathrm{cd}}$ & $0.44^{\mathrm{cd}}$ & $0.27^{\mathrm{c}}$ \\
\hline F & $12.09^{\mathrm{e}}$ & $0.51^{\mathrm{d}}$ & $0.54^{\mathrm{de}}$ & $0.37^{\mathrm{d}}$ \\
\hline G & $9.09^{\mathrm{d}}$ & $0.31^{\mathrm{e}}$ & $0.45^{\mathrm{b}}$ & $0.28^{\mathrm{de}}$ \\
\hline H & $12.10^{\mathrm{f}}$ & $0.52^{\mathrm{f}}$ & $0.55^{\mathrm{c}}$ & $0.38^{\mathrm{e}}$ \\
\hline
\end{tabular}

Mean with the same superscript along the same column are not significantly different $(p>0.05)$ Sample A $=100 \%$ WF 
Sample B $=90 \% \mathrm{WF}, 10 \%$ GFM, 0\% AYB

Sample C $=80 \%$ WF, 20\% GFM, 0\% AYB

Sample D=70\% WF, 30\% GFM, 0\% AYB

Sample E $=70 \% \mathrm{WF}, 20 \%$ GFM, $10 \%$ AYB

Sample F=60\% WF, 30\% GFM, 10\% AYB

Sample G=70\% WF, 10\% GFM, 20\% AYB

Sample H=50\% WF, 30\% GFM, $20 \%$ AYB

\section{Anti-Nutritional Contents of the Flour}

The anti-nutritional contents of the flour samples are as shown in Table 4. The tannin, phytate, oxalate and trypsin ranged from 0.0074 to $0.0098 \%, 0.1700$ to $0.1990 \%, 0.0905$ to $0.1080 \%$ and 1.2500 to $1.4900 \%$, respectively. It was observed that increase occurred in the anti-nutritional value present as finger millet and African yam bean flour is been added. There was a general reduction in these antinutrients which could be attributed to germination of the finger millet and the roasting effect on the African yam beam seeds (Abioye et al., 2018). However, the levels of these anti-nutrients in all the samples were relatively low and may not hinder the bioavailability of essential nutrients in the flours.

Table 4: Anti-Nutritional Properties of Flour (mg/ $100 \mathrm{~g}$ )

\begin{tabular}{|l|l|l|l|l|}
\hline Sample & Tannin & Phytate & Oxalate & Trypsin inhibitor \\
\hline A & $0.0074^{\mathrm{a}}$ & $0.1700^{\mathrm{a}}$ & $0.0905^{\mathrm{a}}$ & $1.2500^{\mathrm{a}}$ \\
\hline B & $0.0081^{\mathrm{b}}$ & $0.1825^{\mathrm{b}}$ & $0.0970^{\mathrm{b}}$ & $1.2750^{\mathrm{ab}}$ \\
\hline C & $0.0086^{\mathrm{b}}$ & $0.1870^{\mathrm{c}}$ & $0.1030^{\mathrm{c}}$ & $1.3300^{\mathrm{b}}$ \\
\hline E & $0.0098^{\mathrm{c}}$ & $0.1990^{\mathrm{de}}$ & $0.1080^{\mathrm{de}}$ & $1.4900^{\mathrm{cd}}$ \\
\hline F & $0.0102^{\mathrm{d}}$ & $0.2060^{\mathrm{e}}$ & $0.1115^{\mathrm{e}}$ & $1.5500^{\mathrm{de}}$ \\
\hline G & $0.0106^{\mathrm{e}}$ & $0.2125^{\mathrm{f}}$ & $0.1170^{\mathrm{f}}$ & $1.6250^{\mathrm{e}}$ \\
\hline H & $0.0110^{\mathrm{e}}$ & $0.2150^{\mathrm{f}}$ & $0.1175^{\mathrm{f}}$ & $1.6050^{\mathrm{e}}$ \\
\hline
\end{tabular}

Mean with the same superscript along the same column are not significantly different $(p>0.05)$. Sample A $=100 \% \mathrm{WF}$

Sample B $=90 \% \mathrm{WF}, 10 \%$ GFM, 0\% AYB

Sample C $=80 \%$ WF, 20\% GFM, 0\% AYB

Sample D=70\% WF, 30\% GFM, 0\% AYB

Sample E $=70 \%$ WF, 20\% GFM, 10\% AYB

Sample F $=60 \% \mathrm{WF}, 30 \%$ GFM, $10 \%$ AYB

Sample G=70\% WF, $10 \%$ GFM, 20\% AYB

Sample H=50\% WF, 30\% GFM, $20 \%$ AYB

\section{Functional Properties of the Flour}

The functional properties of the composite flour are as shown in Table 5. The bulk density of the composite flour ranged from 0.66 to $0.67 \mathrm{~g} / \mathrm{ml}$. There were differences in the values of the bulk density but not all are significantly different from each other. Bulk density is an indication of the porosity of a product which influences packages design and could be used to determine the type of packaging material required for the product. The water absorption capacity and oil water capacity ranged from 106.65 to $124.70 \mathrm{~g} / 100 \mathrm{~g}$ and $91.70-99.75 \mathrm{~g} / 100 \mathrm{~g}$. Higher levels were recorded with germinated finger millet flour and African yam bean flour substitution. Similar trend was also reported for maize-cowpea "kokoro" blends (Abegunde et al., 2014). Water absorption 
and oil absorption capacities are reported to be influenced by the nature and behaviour of seed macromolecules especially, protein and the nature of starch (Finney, 1994; Henshaw and Sobowale, 1996). Adebowale et al. (2005) and Oladipo and Nwokocha (2011) attributed high water absorption capacity to loose structure of starch polymers while low value indicates compactness of the structure. The high-water absorption capacity of the flour blends is an indication that the composite flour will perform useful function in baked products during dough making stage. Iwe and Onadipe (2001) also reported that the ability of flour to absorb water improved dough making potentials.

The foaming capacity and foaming stability of the flour samples ranged from 25.87 to 27.48 and 6.11 to 8.12 , respectively with the sample with $100 \%$ having the lowest value. Higher foaming capacity and foaming stability were observed as finger millet and African yam bean flour were substituted into the composite flour. Foamability is related to the rate of decrease in the surface tension of the air-water interface caused by absorption of protein molecules (Eke and Akobundu, 1993; Mepha et al., 2007). Foaming capacity and foaming stability contribute to dough formation and stability (Olapade and Oluwole, 2013). High foaming capacity and foaming stability is a criteria for good quality product (Achinewhu et al., 1998).

Table 5: Functional Properties of Composite Flour

\begin{tabular}{|l|l|l|l|l|l|}
\hline Sample & $\begin{array}{c}\text { LBD } \\
(\mathbf{g} / \mathbf{m l})\end{array}$ & $\begin{array}{c}\text { WAC } \\
(\mathbf{g} / \mathbf{1 0 0 g})\end{array}$ & $\begin{array}{c}\text { OAC } \\
(\mathbf{g} / \mathbf{1 0 0 g})\end{array}$ & $\begin{array}{l}\text { FC } \\
(\mathbf{\%})\end{array}$ & $\begin{array}{l}\text { FS } \\
(\mathbf{\%})\end{array}$ \\
\hline A & $0.66^{\mathrm{a}}$ & $106.65^{\mathrm{a}}$ & $91.70^{\mathrm{a}}$ & $25.87^{\mathrm{a}}$ & $6.11^{\mathrm{a}}$ \\
\hline B & $0.67^{\mathrm{a}}$ & $113.50^{\mathrm{b}}$ & $92.80^{\mathrm{b}}$ & $26.04^{\mathrm{ab}}$ & $6.20^{\mathrm{a}}$ \\
\hline C & $0.67^{\mathrm{a}}$ & $115.35^{\mathrm{c}}$ & $93.30^{\mathrm{b}}$ & $26.23^{\mathrm{b}}$ & $6.94^{\mathrm{b}}$ \\
\hline D & $0.67^{\mathrm{a}}$ & $118.35^{\mathrm{d}}$ & $96.80^{\mathrm{c}}$ & $26.68^{\mathrm{c}}$ & $7.02^{\mathrm{b}}$ \\
\hline E & $0.67^{\mathrm{a}}$ & $119.50^{\mathrm{d}}$ & $97.60^{\mathrm{d}}$ & $26.68^{\mathrm{c}}$ & $7.07^{\mathrm{bc}}$ \\
\hline F & $0.67^{\mathrm{a}}$ & $121.40^{\mathrm{e}}$ & $98.35^{\mathrm{e}}$ & $27.37^{\mathrm{d}}$ & $7.14^{\mathrm{bc}}$ \\
\hline G & $0.67^{\mathrm{a}}$ & $122.55^{\mathrm{e}}$ & $98.85^{\mathrm{e}}$ & $27.40^{\mathrm{d}}$ & $7.60^{\mathrm{cd}}$ \\
\hline H & $0.67^{\mathrm{a}}$ & $124.70^{\mathrm{f}}$ & $99.75^{\mathrm{f}}$ & $27.48^{\mathrm{d}}$ & $8.12^{\mathrm{d}}$ \\
\hline
\end{tabular}

Mean with the same superscript along the same column are not significantly different $(p>0.05)$.

Mean with the same superscript along the same column are not significantly different $(p>0.05)$

Sample A $=100 \% \mathrm{WF}$

Sample B $=90 \% \mathrm{WF}, 10 \%$ GFM, 0\% AYB

Sample C $=80 \%$ WF, $20 \%$ GFM, 0\% AYB

Sample D=70\% WF, 30\% GFM, 0\% AYB

Sample E $=70 \%$ WF, 20\% GFM, 10\% AYB

Sample F $=60 \% \mathrm{WF}, 30 \%$ GFM, $10 \%$ AYB

Sample G=70\% WF, 10\% GFM, 20\% AYB

Sample H=50\% WF, 30\% GFM, $20 \%$ AYB

\section{Sensory Evaluation of Cookies}

The sensory evaluation of cookies produced from the composite flour of wheat, germinated finger millet and African yam bean flour are as shown in Table 6. The result shows that the cookies produced from the wheat flour had better acceptability probably because people were familiar with the products. Cookies made from $90 \%$ wheat flour and $10 \%$ germinated finger millet had close 
level of acceptability. While the samples with 20-30 germinated finger millet flour and 20\% African yam bean had good rating.

Table 5: Sensory Evaluation of Cookies

\begin{tabular}{|l|l|l|l|l|l|l|}
\hline Sample & Colour & Flavor & Taste & Texture & Appearance & Overall acceptability \\
\hline A & $8.30^{\mathrm{d}}$ & $7.95^{\mathrm{b}}$ & $7.90^{\mathrm{c}}$ & $7.80^{\mathrm{c}}$ & $8.00^{\mathrm{d}}$ & $8.00^{\mathrm{c}}$ \\
\hline B & $8.00^{\mathrm{d}}$ & $7.95^{\mathrm{d}}$ & $7.95^{\mathrm{c}}$ & $8.20^{\mathrm{c}}$ & $8.00^{\mathrm{d}}$ & $8.00^{\mathrm{c}}$ \\
\hline C & $7.10^{\mathrm{cd}}$ & $7.30^{\mathrm{abc}}$ & $7.00^{\mathrm{cd}}$ & $7.00^{\mathrm{bc}}$ & $6.40^{\mathrm{bcd}}$ & $7.00^{\mathrm{bc}}$ \\
\hline D & $7.10^{\mathrm{cd}}$ & $6.60^{\mathrm{ab}}$ & $6.85^{\mathrm{cd}}$ & $5.60^{\mathrm{ab}}$ & $5.40^{\mathrm{abc}}$ & $5.80^{\mathrm{abc}}$ \\
\hline E & $5.25^{\mathrm{a}}$ & $5.15^{\mathrm{a}}$ & $5.10^{\mathrm{a}}$ & $4.80^{\mathrm{a}}$ & $4.20^{\mathrm{ab}}$ & $4.00^{\mathrm{a}}$ \\
\hline F & $6.30^{\mathrm{c}}$ & $6.25^{\mathrm{ab}}$ & $6.00^{\mathrm{ab}}$ & $5.80^{\mathrm{d}}$ & $5.60^{\mathrm{abc}}$ & $5.20^{\mathrm{ab}}$ \\
\hline G & $5.90^{\mathrm{b}}$ & $5.60^{\mathrm{a}}$ & $5.90^{\mathrm{a}}$ & $5.40^{\mathrm{ab}}$ & $5.00^{\mathrm{abc}}$ & $5.40^{\mathrm{ab}}$ \\
\hline H & $6.60^{\mathrm{d}}$ & $6.25^{\mathrm{ab}}$ & $5.90^{\mathrm{a}}$ & $5.60^{\mathrm{ab}}$ & $5.80^{\mathrm{abc}}$ & $5.80^{\mathrm{abc}}$ \\
\hline I & $5.00^{\mathrm{a}}$ & $5.10^{\mathrm{a}}$ & $5.20^{\mathrm{a}}$ & $5.40^{\mathrm{ab}}$ & $3.80^{\mathrm{a}}$ & $4.00^{\mathrm{a}}$ \\
\hline J & $6.25^{\mathrm{c}}$ & $6.30^{\mathrm{ab}}$ & $6.15^{\mathrm{ab}}$ & $5.40^{\mathrm{ab}}$ & $4.20^{\mathrm{ab}}$ & $5.00^{\mathrm{ab}}$ \\
\hline K & $5.30^{\mathrm{d}}$ & $6.95^{\mathrm{b}}$ & $5.90^{\mathrm{c}}$ & $6.80^{\mathrm{c}}$ & $6.00^{\mathrm{d}}$ & $4.00^{\mathrm{c}}$ \\
\hline
\end{tabular}

Mean with the same superscript along the same column are not significantly different $(p>0.05)$ Sample A $=100 \% \mathrm{WF}$

Sample B $=90 \% \mathrm{WF}, 10 \%$ GFM, 0\% AYB

Sample C $=80 \% \mathrm{WF}, 20 \%$ GFM, 0\% AYB

Sample D $=70 \% \mathrm{WF}, 30 \%$ GFM, 0\% AYB

Sample E $=70 \%$ WF, 20\% GFM, 10\% AYB

Sample F=60\% WF, 30\% GFM, $10 \%$ AYB

Sample G $=70 \%$ WF, $10 \%$ GFM, 20\% AYB

Sample H=50\% WF, 30\% GFM, $20 \%$ AYB

\section{Conclusion and Recommendation}

This study has shown that there was a notable increment in the nutritional value with increase in the level of substitution of germinated finger millet and roasted African yam bean. The germination and the roasting as processing techniques improved the nutritional value of the flour mixes and reduced the antinutrients which have been a limiting factor in the use of these crops. It could also be inferred from this study that acceptable and good quality cookies could be produced from composite flour of wheat, germinated finger millet flour and African yam bean.

\section{References}

[1] Abegunde, T. A., Bolaji, O. T. and Adeyemo, T. M. 2014. Quality evaluation of maize chips ("kokoro") fortified with cowpea flour. Nig. Food J., 32(1):97-104.

[2] Abioye V.F., Ogunlakin, G.O, Taiwo, G 2018. Effect of germination on anti-oxidant activity, total phenols, flavonoids and anti-nutritional content of finger millet flour. Food Process Technol 2018, 9:2.

[3] Achinewhu,. S.C., Barber, L.I., Ijeoma, I.O. 1998. Physicochemical properties and garrification of selected cassava cultivars in river state. Plant Foods Hum Nutr.; 52:133-140.

[4] Adebowale, A. A., Sanni, L. O., Awonorin, S. O. 2005. Effect of texture modifiers on the physicochemical and sensory properties of dried "fufu". Food Sci. Technol., 11:373-385Adeleke R. O., 
and Odedeji J. O.. 2010. Functional properties of wheat and sweet potato flour blend. Pakistan J Nutr., 96:535-538

[5] Adeyeye, S.A., Akingbala, J.O 2015. Quality characteristics and acceptability of cookies from sweet potato - maize flour blends. Nutrition and Food Science, Vol. 45 (5): 703-715.

[6] Agriga, A.N., Iwe, M.O. 2009. Proximate composition of cookies produced from cassava groundnut-corn starch blend. Nig. Food J., 27: 102-107.

[7] Ajanaku, K.O., Dawodu., F.A., Ajanaku, C.O., O.C. Nwinyi. 2011. "Functional and Nutritional Properties of Spent Grains Enhanced Cookies". American Journal of Food Technology, 6:763-771.

[8] Akubor, P.I., Ukwuru, M.U 2005. Functional properties and biscuit making potential of soybean and cassava flour blends, Plants Foods for Human Nutrition, 58: 1-12.

[9] Amadou, I., Gounga, M.E., Guo-Wei Le 2013. Millets: Nutritional composition, some health benefits and processing - A review. Emir. J. Food Agric., 25 (7): 501-508.

[10] Annunziata A., Pascale, P. 2009. Consumers' behaviours and attitudes toward healthy food products: The case of Organic and Functional foods. Paper prepared for presentation at the 113th EAAE Seminar "A resilient European food industry and food chain in a challenging world", Chania, Crete, Greece, September, 3 - 6, 2009.

[11] Aremu, C.O., Ibirinde, D.B. 2012. Bio-diversity Studies on Accessions of African Yam Bean (Sphenostylis stenocarpa). International Journal of Agricultural Research Volume 7 (2): 78-85.

[12] Arntfield, S.D., Ismond, M.A.H., Murray, E.D. 1985. The fate of antinutritional factors during the preparation of the faba bean protein isolate using micellization techniques," Canadian Institute of Food Science and Technology Journal, Vol. 18 (2): 137-143.

[13] Atobatele, O.B., Afolabi, M.O., 2016. Chemical composition and sensory evaluation of cookies baked from the blends from the blends of soya bean and maize flours. Applied Tropical Agriculture Volume 21, No.2 (Special Issue), 8-13

[14] Azeke, M.A., Barbara, F., Ham, B.P., Whelm, H and Thomas, B. 2005. Nutritional value of AYB (Sphenostylis stenocarpa). Improvement by lactic acid fermentation. J.Sci. Food Agric, 85(6):963970.

[15] Ceserani, V., Kinton, R 2008. Practical Cookery (10th ed.), John Wiley and Sons, New York.

[16] Chandrasekara, A., Shahidi. F. 2010. Content of insoluble bound phenolics in millets and their contribution to antioxidant capacity. J. Agric. Food Chem., 58:6706-6714.

[17] Chinma, C.E., Gernah, D.I. 2007. Physicochemical and sensory properties of cookies produced from cassava/soyabean/mango composite flours. J. Food Technol., 5:256-260.

[18] Devi, P. B., Vijayabharathi, R., Sathyabama, S., Malleshi, N.G and Priyadarisini, V.B. 2011. Health benefits of finger millet (Eleusine coracana L.) polyphenols and dietary fiber: a review. J. Food Sci. Technol., DOI: 10.1007/s13197-011-0584-9

[19] Eke, O. S., Akobundu, E. H. T. 1993. Functional properties of African yam bean (Sphenostylis stenocarpa) seed flour as affected by processing. J. Food Chem., 48:337-340.

[20] Finney, K. F. 1994. Contribution of individual chemical constituents to the functional (bread making) properties of wheat. 1994, Cereals 78 better nutrition for the Worlds Millions St. Paul: AACC Publication, Pp. 139-158.

[21] Ghavidel, R.A., Prakadh, J. 2007. The impact of germination and dehulling on nutrients ,antinutrients, in vitro iron and calcium bioavailability and in vitro starch and protein digestibility of some legumes seeds. LWT, 40:1292-1299.

[22] Henshaw, F. O., Sobowale, M. K. 1996. Cowpea flour produced from different bean varieties: Functional properties, composition and acceptability of products. Nig. Food J., 14:62-70.

[23] Ikuomola1, Otutu, O.L., Oluniran, D.D. Quality assessment of cookies produced from wheat flour and malted barley (Hordeum vulgare) bran blends. Cogent Food \& Agriculture, 3: 1293471.

[24] Iwe, M. O., Onadipe, O. O. Effect of extruded full fat soy flour into sweet potato flour on functional properties of the mixture. J. Sustain Agric. Environ. 2001, 3(1):109-117. 
[25] Kulkarni, S.D (1997). Roasted Soybean in Cookies: Influence on Product Quality. J Food Sci. Technology-mysore, 34: 503-505.

[26] Kumar, A., Metwal, M., Kaur, S., Gupta, A.K., Puranik, S., Singh, S., Singh, M., Gupta, S., Babu, B.K., Sood, S., Yadav, S. 2016. Nutraceutical Value of Finger Millet [Eleusine coracana (L.) Gaertn.], and Their Improvement Using Omics Approaches. Front Plant Sci., 7: 934.

[27] Makkar HPS, Blummed MB, Becken NK 1993. Determination of tannins and their correlation with chemical and protein precipitation method. J. Food Sci. Agric., 61:161 185

[28] Moyib, O.K., Gbadegesin, M.A., Aina, O.O., Odunola, O.A 2008. Genetic variation within a collection of Nigerian asccessions of African yam bean (Sphenostylis stenocarpa) revealed by RAPD primers. Afr. J. Biotechnol, 7(12): 1839-1846.

[29] Narayana, K., Narsinga Rao, M.S. 1982. Functional properties of war and heat processed winged bean (Psophocarpus tetragonolobus) flour. J Food Sci., 42:534-538.

[30] Ndidi, U. S., Ndidi, C. U., Abbas, O., Aliyu, M., Francis, G. B. and Oche, O. 2014. Proximate, antinutrients and mineral composition of raw and processed (Boiled and Roasted) Sphenostylis stenocarpa seeds from Southern Kaduna, Northwest Nigeria. http://dx.doi.org/10.1155/2014/280837.

[31] Obasi, N.E., Uchechukwu, N and Eke-Obia, E. 2012. Production and Evaluation of Biscuits from African Yam Bean (Sphenostylis stenocarpa) and Wheat (Triticum aestivum) Flours. Food Science and Quality Management www.iiste.org ISSN 2224-6088 (Paper) ISSN 2225-0557 (Online) Vol 7, 2012.

[32] Obilana, A. B., and Manyasa, E. 2002. "Millets," in Pseudocereals and Less Common Cereals. Grain Properties and Utilization Potential, eds P. S. Belton and J. R. N. Taylor (Berlin: SpringerVerlag). Pp.176-217

[33] Ogunlakin, G.O., Oke, M.O., Babarinde, G.O and Olatunbosu, D.G. 2012. Effect of drying methods on proximate composition and physico-chemical properties of cocoyam flour. American Journal of Food Technology, 7: 245-250.

[34] Ojinnaka, M. C., Okakpu, C. J., Ihemeje, A. and Onuobia, F. D. 2017. Nutrient composition and functional properties of african yam bean (Sphenostylis stenocarpa) flour and protein isolates. Nigerian Journal of Agriculture, Food and Environment,13(4):45-49.

[35] Okaka, J.C and Potter, N.N. 1977. Functional and storage properties of cow pea-wheat flour blends in bread making. J Food Sci.,42:828-833.

[36] Okoye, J. I., Ezigbo, V. O.and Animalu. I.I. 2010. Development and quality evaluation of weaning food fortified with african yam bean (Sphenostylis stenocarpa) flour. Continental J. Agricultural Science, $4: 1-6$.

[37] Okpala, L.C and Okoli, E.C.2011. Nutritional evaluation of cookies produced from blends of pigeon peas, cocoyam and sorghum flour blends. Afr. J. Biotechnol., 10:433-438.

[38] Oladipo, F. Y. and Nwokocha, L. M. 2011. Effect of Sida acuta and Corchorous olitorius mucilages on the physico-chemical properties of maize and sorghum starches. Asian J. Applied Sci., 4:514525 .

[39] Olapade, A.A and Adeyemo, A.M. Evaluation of cookies produced from blends of wheat, cassava and cowpea flours. International Journal of Food Studies,Vol. 3:175-185.

[40] Olapade, A. A. and Oluwole, O. B. 2013. Bread making potential of composite flour of wheatacha (Digitaria exilis staph) enriched with cowpea (Vigna unguiculata L. Walp) flour. Nig. Food J., 31(1):6-12.

[41] Mepha, D. H., Luayt, J. and Niraojigoh, S. U. 2007. Chemical composition, functional and baking properties of wheat plantain composite flour. Afr. J. Food Agric. Nutr. Dev., 7(1):1-22.

[42] Onuoha, C.H., Harry, B.J. and Eze, S O. 2017. Evaluation of nutrients and anti-nutritional Factors of different species of African yam bean (Sphenostylis stenocarpa). European Journal of Basic and Applied Sciences Vol. 4 (1): 2059-3058. 
[43] Oyeyinka, S.A., Oyeyinka, A.T., Karim, O.R., Kayode, R. M.O., Balogun, M.A., Balogun O.A. (2013): Quality sttributes of Weevils (Callosobruchus Maculatus) infested cowpea (Vigna Unguiculata) products. Nig. J. of Agric. Food. and Environ., 9 (3), 16-22.

[44] Pearson D (1976). The Chemical analysis of foods. (7th ed.). Churchill, Livingstone.

[45] Sengev, I.A., Gernah, D.I and Bunde-Tsegba, M C. Physical, chemical and sensory properties of cookies produced from sweet potato and mango mesocarp flours. African Journal of Food, Agriculture, Nutrition and Development, Vol.15(5): 10429-10442.

[46] Singh, J., Singh, N., Sharma, T.R and Saxena, S.K. 2003. Physicochemical, rheological and cookie making properties of corn and potato flours. Food Chem., 83: 387-393.

[47] Soetan, K.O and Oyewole, O.E. 2009. The need for adequate processing to reduce the antinutritional factors in plants used as human foods and animal feeds: A review. African Journal of Food Science, 3 (9): 223-232.

[48] Sokrab, A.M., Mohamed Ahmed, I.A and Babiker, E.E. 2014. Effect of fermentation on antinutrients, and total and extractable minerals of high and low phytate corn genotypes. J Food Sci. Technol., 51(10): 2608-2615.

[49] Taiwo, E.O., Sekinat, A.A.. Adegbola, D.O., Arise, A.K. and Sotunde, A.J. $\quad$ 2017.Chemical composition and sensory qualities of wheat-sorghum date cookies. Croatian Journal of Food Technology, Biotechnology and Nutrition, 12 (1-2):71-76.

[50] Ubbor, S.C and Akobundu, E.N.T. 2009. Quality characteristics of cookies from composite flours of watermelon seed, cassava and wheat. Pakistan J. Nutr., 8:1097-1102.

[51] Vinoth, A and Ravindhran' R. 2017. Biofortification in Millets: A Sustainable Approach for Nutritional Security. Front Plant Sci., 8: 29.

[52] Wafula, W.N., Korir, N.K., Ojulong, H.F., Siambi, M and Gweyi-Onyango, J.P. Protein, Calcium, Zinc, and Iron Contents of Finger Millet Grain Response to Varietal Differences and Phosphorus Application in Kenya. Agronomy. 8, 24; 1-9.

*Corresponding author.

E-mail address: vfabioye@ lautech.edu.ng 